\title{
Salmon Calcitonin Induced Head Twitch in the Rat
}

\author{
Renato GAGGI and Rosaria DE IASIO \\ Institute of Pharmacology. University of Bologna, School of Medicine. \\ Via Irmerio 48, 40126 Bologna, Italy \\ Accepted January 30. 1988
}

\begin{abstract}
The intracerebroventricular administration of salmon calcitonin (SCT) to rats induced a dose-dependent increase in the number of head twitches and potentiated such a response elicited by L-5-hydroxytryptophan (L-5-HTP). Subcutaneously administered SCT was ineffective "per se" but could again potentiate the head twitch response elicited by L-5-HTP. Since these data suggest a stimulation of the brain serotonergic pathways, the obtained results support the hypothesis that some central actions of SCT may involve activation of serotonergic systems in the rat brain.
\end{abstract}

It has been reported that salmon calcitonin ( $\mathrm{SCT}$ ), injected intracerebroventricularly (i.c.v.) in the rat, increases the levels of 5 hydroxyindolacetic (5-HIAA) acid in the cerebellum, pons, hypothalamus and striatum. In the same rats, serotonin $(5-H T)$ levels are increased only in the cerebellum and the pons, and they are unchanged in other brain areas (1).

On the other hand, subcutaneous (s.c.) administration of $\mathrm{SCT}$ induced a marked increase of both 5-HT (2) and 5-HIAA (R. Gaggi, unpublished observation) levels in the rat brain. Since these neurochemical changes are generally considered as an index of activation of the brain serotonergic system, the administration of SCT should be followed by modification of serotonergic behavioral responses. In a previous study (3). it has been assumed that the anorectic effect of SCT was achieved by making more $5-\mathrm{HT}$ available in the synaptic cleft; this action seemed to be mediated by an increase in the synthesis and/or release of the neurotransmitter. The present study was aimed to verify whether or not SCT given either s.c. or i.c.v. to rats could induce head-twitch behavior or potentiated the same response elicited by the 5-HT precursor L-5-hydroxytryptophan (L-5-HTP). It is generally accepted that L-5-HTP elicits head-twitch by increasing 5-HT and 5-HIAA levels in the brain. A s.c. or i.c.v. pretreatment with $\mathrm{SCT}$ should enhance this increase. Head twitches were chosen as they are a quantifiable and reliable measure of serotonergic activation: the response is dose-related and appears even in the presence of low doses of 5-HT agonists (4). Male Sprague Dawley rats (Nossan. Milano, Italy) weighing $250-300 \mathrm{~g}$ were used. They were housed under controlled conditions of light (7.00 a.m. -7.00 p.m. ), temperature $\left(22 \pm 2^{\circ} \mathrm{C}\right)$ and humidity $(65 \%)$ and were allowed free access to standard laboratory diet and tap water. SCT was kindly supplied by Sandoz (Basel) as commercial vials (containing $100 \mathrm{MRCU}=20$ $\mu \mathrm{g}$ of peptide, $2 \mathrm{mg}$ of acetic acid. $2 \mathrm{mg}$ of sodium acetate. $7.5 \mathrm{mg}$ of sodium chloride and distilled water to $1 \mathrm{ml}$ volume) and as pure powder. As needed, these vials were diluted with saline, and SCT was s.c. injected at the doses of $5,10,20,40$ and $80 \mu \mathrm{g} / \mathrm{kg}$; control rats received $4 \mathrm{ml} / \mathrm{kg}$ of saline containing acetic acid. I.c.v. injected rats were implanted, at least 7 days before the behavioral trials, with permanent plastic cannulae entering the right ventricle. By this route, the powder form of sCT dissolved in sterile saline containing $0.5 \%$ human albumin was administered at the doses of $0.1,0.2 .0 .4$ and $0.8 \mathrm{~kg} / \mathrm{rat}$; control animals received only vehicle $(20 \mu \mathrm{l} / \mathrm{rat})$. Immediately after treatment, the rats were put into transparent plexiglas cylinders $(20 \mathrm{~cm}$ diameter, $25 \mathrm{~cm}$ height), and $30 \mathrm{~min}$ later, the head-twitches exhibited by the animals 
Table 1. Number of head-twitches elicited in $90 \mathrm{~min}$ by various doses of L- 5 -hydroxytryptophan (L5 -HTP) subcutaneously administered to rats s.c. or i.c.v. pretreated with vehicles or salmon calcitonin $(\mathrm{SCT})$

\begin{tabular}{|c|c|c|c|c|}
\hline \multirow{2}{*}{$\begin{array}{l}L-5-H T P \\
(\mathrm{mg} / \mathrm{kg})\end{array}$} & \multicolumn{2}{|c|}{ s.c. pretreatment } & \multicolumn{2}{|c|}{ i.c.v. pretreatment } \\
\hline & $\begin{array}{c}\text { vehicle } \\
(4 \mathrm{ml} / \mathrm{kg})\end{array}$ & $\begin{array}{c}\mathrm{sCT} \\
(20 \mu \mathrm{g} / \mathrm{kg})\end{array}$ & $\begin{array}{l}\text { vehicle } \\
(20 \mu 1 / \text { rat })\end{array}$ & $\begin{array}{c}\mathrm{SCT} \\
(0.1 \mu \mathrm{g} / \mathrm{rat})\end{array}$ \\
\hline 0 & $\begin{array}{c}28.5 \pm 5.8 \\
(8)\end{array}$ & $\begin{array}{c}25.3 \pm 7.1 \\
(8)\end{array}$ & $\begin{array}{c}15.0 \pm 4.2 \\
(12)\end{array}$ & $\begin{array}{c}30.5 \pm 9.5 \\
(12)\end{array}$ \\
\hline 12.5 & $\begin{array}{c}33.6 \pm 11.9 \\
(8)\end{array}$ & $\begin{array}{c}17.3 \pm 3.6 \\
(8)\end{array}$ & $\begin{array}{c}33.0 \pm 10.3 \\
(8)\end{array}$ & $\begin{array}{c}50.0 \pm 9.5 \\
(8)\end{array}$ \\
\hline 25.0 & $\begin{array}{c}42.9 \pm 11.4 \\
(8)\end{array}$ & $\begin{array}{c}66.0 \pm 17.8 \\
(8)\end{array}$ & $\begin{array}{c}38.9 \pm 11.2 \\
(7)\end{array}$ & $\begin{array}{c}111.4 \pm 12.8^{*} \\
(7)\end{array}$ \\
\hline 50.0 & $\begin{array}{c}49.9 \pm 12.4 \\
(8)\end{array}$ & $\begin{array}{c}104.4 \pm 15.9^{*} \\
(8)\end{array}$ & $\begin{array}{c}56.8 \pm 15.9 \\
(6)\end{array}$ & $\begin{array}{c}109.0 \pm 26.6^{*} \\
(6)\end{array}$ \\
\hline 100.0 & $\begin{array}{c}126.0 \pm 19.7 \\
(8)\end{array}$ & $\begin{array}{c}187.9 \pm 26.1^{*} \\
(8)\end{array}$ & - & - \\
\hline
\end{tabular}

Values are means \pm S.E. (in brackets, the number of rats). "Significantly different $(P<0.05)$ when compared to the corresponding control.

were counted for $60 \mathrm{~min}$ by an experienced observer unaware of the treatments. The obtained data were submitted to linear regression analysis. As far as effect on headtwitch response to $L-5-H T P$, the rats were pretreated with sCT either s.C. $(20 \mu \mathrm{g} / \mathrm{kg})$ or i.c.v. $(0.1 \mu \mathrm{g} / \mathrm{rat})$. Control groups received the respective vehicle. Thirty min later, all the animals were i.p. treated with $25 \mathrm{mg} / \mathrm{kg}$ of the decarboxylase inhibitor $\alpha$-methyldopa hydrazine (carbidopa, kindly supplied by Merck, Sharp and Dhome, West Point, U.S.A.). After an additional thirty min, the rats were s.c. injected with different doses (see Table 1) of L-5-HTP (Sigma, St. Louis, U.S.A.) dissolved in saline containing a few drops of $\mathrm{HCl} 0.1 \mathrm{~N}$. The head twitch responses were counted for 90 min starting 15 min after the L-5-HTP injection. Statistical analysis was performed by means of two-way factorial ANOVA (sCT $\times$ L-5-HTP). Since a significant "sCT $\times$ L-5-HTP doses" interaction was obtained, saline pretreated groups were compared to the respective SCT pretreated groups within each level of the factor " $L-5$ HTP dose".

The s.c. or i.c.v. administered sCT did not produce excitation. depression or other nonspecific effects on the rat behavior. On the other hand, the administered doses were high enough to reduce both food and water intake (5). Moreover, most of the i.c.v. treated rats exhibited "tail whipping", as already des-

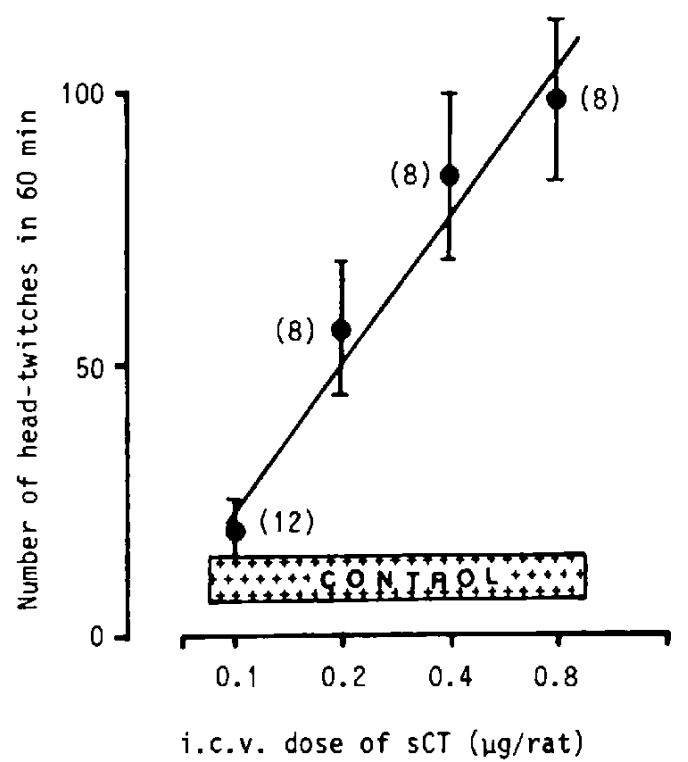

Fig. 1. Relationship between the log-dose of sCT and the number of head twitches. Values are expressed as the mean \pm S.E.M. (in brackets, the number of rats). In the reported range, the response was linearly related to the log-dose of $\mathrm{sCT} \quad(r=0.910$. $P<0.01$ ).

cribed (6). All these effects were not evaluated. Figure 1 shows the head-twitch response exhibited by i.c.v. injected rats: whereas control animals showed few head twitches $(10.6 \pm 1.8, n=36)$. sCT treated rats showed a dose-dependent increase of such a 
response. On the contrary, s.c. administered SCT did not change the rat head twitch response at any tested dose (data not shown). On the other hand, head twitch response elicited by L-5-HTP was significantly potentiated by the peptide injected either s.c. (at the dose of $20 \mu \mathrm{g} / \mathrm{kg})(\mathrm{F} \mathrm{1.70=6.71;P<}$ 0.01 ) or i.c.v. (at the dose of $0.1 \mu \mathrm{g} / \mathrm{rat}$ ) (F 1.58=17.27: $P<0.01$ ) (Table 1). The interaction of "sCT $\times$ L-5-HTP doses" was also significant ( $F 4,70=2.74, P<0.05$ and $F 3.58=2.76, P<0.05)$. Data obtained from i.c.v. injections of SCT suggest that the peptide stimulates the brain serotonergic system. In fact. a) sCT directly induced head twitch response and $b$ ) a dose ineffective to change animal behaviour $(0.1 \mathrm{~kg} / \mathrm{rat})$ potentiated the effect of the $5-\mathrm{HT}$ precursor L5-HTP.

Even s.c. given sCT, at dose of $20 \mu \mathrm{g} / \mathrm{kg}$, potentiated the behavioral response induced by L-5-HTP. However. this does not signify that SCT easily passes through the bloodbrain barrier because a dose of $80 \mu \mathrm{g} / \mathrm{kg}$. approximately 100 times higher than the minimal effective i.c.v. dose $(0.2 \mu \mathrm{g} / \mathrm{rat})$, did not induce "per se" head twitch behavior. Therefore the s.c. administration of sCT produced effects similar to those induced by i.c.v. injection but less marked. To explain this discrepancy, we could hypothesize that SCT effects on head twitch behavior are mediated by a direct (more effective) or an indirect (less effective) inhibition of the $\mathrm{Ca}^{2+}$ neuronal influx that, in turn, activates the brain serotonergic systems. In fact, it has been found (7) that sCT inhibits in vitro $\mathrm{Ca}^{2+}$ uptake by hypothalamic neurons. This dosedependent (8) action can be exerted by the i.c.v. but not the s.c. given peptide; on the contrary, S.C. given SCT could operate only by means of a marked and long-lasting hypocalcaemia. This hypocalcaemia might have caused modification of the $\mathrm{Ca}^{2+}$ in the brain resulting in an increased release of 5 $H T$, especially when the neuronal store of the neurotransmitter was increased owing to L-5-HTP administration. In this regard, it is likely that, besides the serotonergic system. many other neuronal systems should be influenced by hypocalcaemia and play a role in the SCT-induced headtwitch behavior.
It has been reported (6) that i.c.v. administered SCT also produces hypocalcaemia. Nevertheless, taken together, the obtained findings agree with the suggestion concerning the involvement of brain serotonergic pathways in some central actions of calcitonins. In fact, it has been reported that a) the anorectic effect of $\mathrm{sCT}$ is strictly related to its ability to activate the serotonergic hypothalamic system (3), b) the analgesic activity of SCT involves a central serotonergic mechanism (9), and c) the stimulation of rat brain acetylcholinesterase activity induced by the porcine calcitonin is mediated by serotonin (10).

In conclusion, the present findings further support the hypothesis that SCT administered either subcutaneously or intracerebroventricularly is able to activate brain serotonergic systems in the rat.

\section{References}

1 Groppetti, A., Flauto, C., Guidobono, F., Parenti, M., Rotondi, G., Soranzio, A. and Tirone, F.: Calcitonin and brain serotonin. In Calcitonin, Edited by Pecile, A., p. 271-278, Excerpta Medica. Amsterdam (1985)

2 Dupuy, B., Peuchant, E., Vitiello, S., Jensen, R., Baghdiantz, A. and Blanquet, P.: Tryptophan and neutral amino acid concentrations in serum of rats after salmon calcitonin injection. Experientia 39, 294-296 (1983)

3 Gaggi, R., Beltrandi, E, Dall'Olio, R., Ferri, S. and Spampinato, S.: Some mechanisms underlying anorexia induced by calcitonin peptides. In Calcitonin, Edited by Pecile, A., p. 261-269. Excerpta Medica, Amsterdam (1985)

4 Matthews, W.D. and Smith, C.D.: Pharmacological profile of a model for central serotonin receptor activation. Life Sci. 26, 1397$1403(1980)$

5 Twery, M.J., Obie, J.F. and Cooper, C.W.: Ability of calcitonins to alter food and water consumption in the rat. Peptides 3, 749-755 (1982)

6 Morimoto, T., Okamoto, M., Koida, M., Nakamuta, H., Stahl, G.L. and Orlowski, R.C.: Intracerebroventricular injection of ${ }^{125}$-salmon calcitonin in rats: fate, anorexia and hypocalcemia. Japan. J. Pharmacol. 37, 21-29 (1985)

7 Levine, A.S. and Morley, J.E.: Reduction of feeding in rats by calcitonin. Brain Res. 222 , 187-191 (1981)

8 Koida, M.. Yamamoto, Y., Nakamuta, H., 
Matsuo, J., Okamoto, M., Morimoto, T., Seyler. J.K. and Orlowski, R.C.: A novel effect of salmon calcitonin on in vitro Ca-uptake by rat brain hypothalamus: the regional and hormonal specificities. Japari. J. Pharmacol. 32, 981-986 (1982)

9 Clementi, G., Prato, A., Conforto, G. and
Scapagnini, U.: Role of serotonin in the analgesic activity of calcitonin. Eur. J. Pharmacol. 98. 449-451 (1984)

10 Nakhla, A.M.: Stimulation of cerebral acetylcholinesterase activity by calcitonin: a possible mediation by 5 -hydroxytryptamine. Hormone Res. 12, 161-164 (1980) 